University of Nebraska - Lincoln

DigitalCommons@University of Nebraska - Lincoln

Publications from USDA-ARS / UNL Faculty

U.S. Department of Agriculture: Agricultural

Research Service, Lincoln, Nebraska

2001

Food Webs, Risks of Alien Enemies and Reform of Biological

Control

D. R. Strong

University of California, Davis

R.W. Pemberton

USDA-ARS

Follow this and additional works at: https://digitalcommons.unl.edu/usdaarsfacpub

Part of the Agricultural Science Commons

Strong, D. R. and Pemberton, R.W., "Food Webs, Risks of Alien Enemies and Reform of Biological Control" (2001). Publications from USDA-ARS / UNL Faculty. 489.

https://digitalcommons.unl.edu/usdaarsfacpub/489

This Article is brought to you for free and open access by the U.S. Department of Agriculture: Agricultural Research Service, Lincoln, Nebraska at DigitalCommons@University of Nebraska - Lincoln. It has been accepted for inclusion in Publications from USDA-ARS / UNL Faculty by an authorized administrator of DigitalCommons@University of Nebraska - Lincoln. 


\title{
Food Webs, Risks of Alien Enemies and Reform of Biological Control
}

\author{
D.R. Strong ${ }^{1}$ and R.W. Pemberton ${ }^{2}$
}

${ }^{1}$ Bodega Marine Laboratory, Section of Evolution and Ecology, 2320 Storer Hall, University of California, Davis, CA 95616, USA; ${ }^{2}$ Invasive Species Research and Biological Control Laboratory, USDA, Agricultural Research Service, 3205 College Ave., Fort Lauderdale, FL 33314, USA

\begin{abstract}
As invasions of alien species mount, biological control will become an increasingly important tool of conservation and agriculture. In an effort to understand indirect interactions in biological control, we review food web ecology in terms of resource competition, trophic cascades, intra-guild predation, apparent competition, omnivory and a diverse set of tri-trophic interactions. The most inclusive study suggests that food webs in biological control are simpler than in natural communities. Risks to non-target species created by biological control have been studied seriously for only about 20 years, and knowledge of these risks is incomplete. The greatest risks are known to be posed by the organisms with the broadest diets, such as vertebrates and the snail Euglandina rosea, which has probably caused the extinction of an entire genus of native snails in Polynesia. Some parasitoid species have been introduced that are sufficiently polyphagous to attack native insects, and cases of serious harm to non-target populations are now coming to light. However, polyphagous organisms continue to be imported for biological control. One case in point is the campaign against the Russian wheat aphid, in which over 8.5 million individual invertebrates, including more than 1 million individuals of 12 species of ladybird beetles new to North America, were released over the past 15 years, with little study of potential non-target effects, direct or indirect. Another case is the new use of the polyphagous black carp for suppression of pest snails in industrial catfish ponds. This fish poses great risks to the high native diversity of molluscs in the Mississippi drainage. We argue that risk to native flora in


biological control of weeds can be judged before introduction. For the New World, the lowest non-target risk comes from stenophagous insects released against weeds with no native congeners. When weeds have native congeners, introductions of even relatively stenophagous insects have led to the use of non-target, native plants.

Restraint is key to safe biological control. First must come judicious winnowing of potential targets. Not every alien species is a threat. Biological control is not the appropriate response to every pest, especially to native species perceived as pests. Second, not every available enemy promises relief. Importing multiple agents in a lottery search for one that might do the job increases the probability of non-target attacks upon the native biota. Restraint can come only from open discussion of risks versus benefits of biological control. What was the basis for the choice of the large number of imported enemy species in the campaign against Russian wheat aphid? What is the calculus of risk versus benefit in the dissemination of the black carp in the Mississippi delta?

Regulation of biological control in the USA is archaic. Oversight derives from a hotchpotch of old legislation designed to serve agriculture, and protection of native species under the current regulatory framework is deficient. Native invertebrates, terrestrial, aquatic and marine, are at greatest risk in the current structure, while native plants have had some, but not full, protection from foreign herbivores imported and disseminated for biological control. Although the ecological and economic value of invertebrates is not widely appreciated, these species are crucial to ecological integrity of our wild, urban and agricultural landscapes. Indirect interactions among native invertebrates can be threatened by alien species, and these contribute to the integrity of natural food webs. The sensible course is to extend Federal protection to minimize the risk to all native organisms. There is also a great need to pay attention to biological control organisms after they are released, and to restrict the propagation and re-release of those that can damage non-target organisms. With invasive species just as with many environmental issues, doing nothing is not neutral. Imported natural enemies are the last best hope to parry some of the most damaging exotic pests in natural areas as well as in agriculture. In the absence of reform, rational as well as irrational opposition to biological control will grow. Only sensible reform will maintain public support for this powerful tool.

\section{Introduction}

\section{Biological control in conservation}

There is nowadays a new effort to understand indirect interactions in biological control. Biological control has much to offer to conservation, 
management and restoration of ecosystems in these times of unprecedented rates of species invasions. Although the fact is poorly appreciated by the public (Colton and Alpert, 1998), invasive weeds are one of the greatest threats to natural areas. Suppression of weeds invading natural areas is the most prominent application of biological control currently employed in conservation. This practice grows out of the earlier use of weed biological control in range management and agriculture (McFadyen, 1998). A prominent example is the irreplaceable role of biological control in weed suppression in the diverse, precious and unique ecosystems of United Nations World Heritage Parks. In the South African Cape fynbos, invasive alien plant species are the greatest threat to the ecological integrity of the community (Olckers and Hill, 1999). Here, biological control is the only sustainable mechanism to suppress these invading weeds. In another World Heritage Site, the Kakadu National Park in Australia's tropical Northern Territory, some 89 species - or about $5 \%$ of the vascular flora - are invasive aliens, and these are judged to be threatening to the nature and conservation status of the Park. Biological control can make a substantial contribution to suppressing these invasive alien species both inside and outside of the Park (Lonsdale and Farrell, 1998). In the Everglades World Heritage Park in Florida, USA, biological control is in progress and planned against the most serious invaders, the Australian melaleuca tree (Center et al., 1997) and Old World climbing fern (Pemberton and Ferriter, 1998). Biological control is also contemplated against insects invading natural areas (Frank, 1999), and even against invasive marine species (Clark et al., 2000).

\section{Food webs, direct and indirect interactions}

The conceptual basis for integrating species interactions is food webs, the 'ecologically flexible scaffolding around which communities are assembled and structured' (Paine, 1996). The simplest kinds of interactions are direct, between pairs of species: competition, predation, parasitism, disease, mutualism. Indirect interactions involve more than two species and are the effects of one species passed via a second to a third species and to others (Menge, 1995). Perhaps the simplest kind of indirect interaction is competition between a pair of species that do not face off but that rely upon a common pool of living, depletable resources. An example of this resource competition in biological control is the suppression of native picture wing flies by the destruction of seeds of native thistles by the introduced Rhinocyllus conicus weevil (Louda et al., 1997; see also Gassmann and Louda, Chapter 8, this volume). Another kind of indirect interaction, termed a trophic cascade, is the protection of a plant by a carnivore that suppresses a herbivore. This is the common goal of biological control of herbivorous insect pests (Hawkins et al., 1999). 
Intra-guild predation is a third type of indirect interaction, in which predators attack both the target species and other species, including other predators and other herbivores. The effects range from suppression of the pest, to no apparent effect upon the target, to the opposite outcome of that desired in biological control (elevation of densities of the pest). Moreover, intra-guild predation of generalist predators in biological control systems can lead to alternative stable states, unstable dynamics and to the generalist predator becoming extinct in the system (Holt and Polis, 1997). Recent research has shown intra-guild predation to be particularly pertinent to biological control (Rosenheim, 1998). Intra-guild predation, ceteris paribus, results in lower consumption rates of the target species than that by a single predator species alone. An example of intra-guild predation in biological control is Zelus bugs (Reduviidae) that feed upon both cotton aphids and lacewing larvae. The lacewing larvae are voracious aphid predators and, when alone, suppress the aphid populations deeply. Although Zelus bugs do eat some aphids, they have virtually no ability to control populations of the herbivore. By feeding upon the lacewing larvae, Zelus bugs disrupt the biological control of the aphid (Cisneros and Rosenheim, 1997). Another example of intra-guild predation, with similarly harmful effects upon biological control, is facultative hyperparasitism (Mills and Gutierrez, 1996).

A fourth kind of indirect interaction is apparent competition, in which one predator species feeds upon two prey species at different rates (Holt and Lawton, 1993; see also Holt and Hochberg, Chapter 2, this volume). Without knowledge of the existence of the predator, the changing densities of the prey would suggest that they were competing when they are not. An example of apparent competition that is a propos to biological control is one aphid species suppressed by a ladybird beetle species that was attracted to the area by the presence of a second aphid species (Müller and Godfray, 1997). In biological control, direct interactions are fairly well known, and indirect interactions are only beginning to be understood. Indirect interactions are much less obvious than direct ecological interactions, and it is only within the past decade, and only in a few systems, that indirect interactions are coming into clear focus. Omnivory is an element of trophic complexity that has led to a broadened concept of food webs for ecologists (Polis and Strong, 1996). In food web omnivory, a single consumer species feeds upon more than one kind of prey, for example, upon a predator species and simultaneously upon a herbivore species. In simple, linear 'top-down' chains of species, omnivory can destabilize interspecific relationships and lead to extinction of one or more species in the chain, while in more complex food webs - with reticulate interconnections omnivory can lead to stability (Fagan, 1997). Stability is an important element of classical biological control, for maintaining suppressive pressure on pest species. Concern about food web omnivory has led to the notion of 'trophic spectra' with differently overlapping connections among 
omnivorous species. It has been argued that trophic spectra are a more accurate concept than discrete trophic levels for the relationships among the consumers and the consumed for many ecological communities (Polis and Strong, 1996).

Self-damping is an element of intraspecific interactions that is extremely important to the stability of interspecific interactions, to food webs and, thus, to biological control (Chesson, 2000). Theoretical work shows how self-damping affects the ability of a natural enemy to suppress its prey or host population (Levins and Schultz, 1996). In many cases, the impact of enemy species on average prey density varies inversely with the strength of self-damping. Predators with severe self-damping often have dynamics out of phase with prey numbers, leading to population cycling and reduced suppression of the prey population. An implication of this is that successful biological control requires a number of, rather than a single, species of agents that experience self-damping. Each of these species contributes modestly, and some uniquely in terms of environmental conditions, to the suppression of the pest. Generalist predators are especially likely to experience self-damping, and this insight complements the findings of Hawkins et al. (1999) that multiple predator species are the mode in natural regulation. Such multiple combinations of predators probably involve webs of interactions that would be difficult to create with introductions of generalist predators for biological control.

Cannibalism is a common form of self-damping for generalist predators, which are important entomophages in both natural and agricultural settings. Cannibalism is a doubled-edged sword for a predator. Consumption of close relatives can lead to loss of inclusive fitness and it carries risks of injury and disease transmission as a result of the prey being so similar to the predator. On the other hand, the commonness of cannibalism among general predators suggests very general benefits that would offset these costs. The rationale of theory of the benefits of cannibalism is that a competitor is eliminated while a meal is gained (Pfennig, 1997; Rosenheim, 1998). Cannibalism can increase as prey densities decrease (Pels and Sabelis, 1999), with the implication for biological control that alien generalist predators can have a particularly great influence in native food webs. Aliens that reduce prey density could increase cannibalism of native predators, and this could reduce the suppression of native herbivores.

Numerical and functional indirect interactions are other elements of food webs that are germane to biological control. Numerical indirect interactions are the simplest sort and those that are most readily modelled. In these, per capita rates of growth and consumption are unaffected by the physical presence of other species: predator species do not avoid each other or otherwise affect each other's behaviour. Numerical indirect interactions include those of general predators that consume the aphid mummies made by a parasitoid in the system (Ferguson and Stiling, 1996). Functional interactions are qualitatively different from numerical ones. 
They are more complicated. Functional interactions include behavioural changes in a predator and/or prey caused by the perception of the presence of the other species (Lima and Dill, 1990); for example, the prey species that refrains from foraging when sensing the presence of a species of predator (Schmitz et al., 1997). Induced resistance of plants by one herbivore species that results in poorer performance of another herbivore species (Karban and Baldwin, 1997) can be considered a functional indirect interaction. Janssen et al. (1998) argue that mite food webs illustrate well the issues of numerical and functional indirect interactions and that the more complex functional indirect interactions are important for biological control involving mites. Compared with natural communities, the mite food webs are not rich in species, while at the same time they are not impoverished in kinds of interactions. Even the fairly simple food webs with mites are reticulate; they are food webs rather than food chains: complex interactions such as apparent competition, intra-guild predation and resource competition are very much a part of the picture to be expected in biological control. This suggests that as our knowledge of other biological control communities increases, equally rich sets of interactions could reveal themselves.

Finally, the rubric 'tri-trophic interactions' is useful for tying in the additional, important kinds of food web effects that do not fit into the neater categories discussed above. Examples include consumption of introduced biological control insects by native species (Pearson et al., 2000), plant manipulation of natural enemy behaviour (Vinson, 1999), simultaneous nourishment of both natural enemy and herbivores in an elaborate form of omnivory (Baggen et al., 1999), influence of a diverse plant community upon the suppression of a herbivore by a parasitoid (Messina et al., 1997), and the reticulate effects of fungal endophytes of plants upon the attack rate upon herbivores by natural enemies (Grewal et al., 1995).

Combined effects of different biological control agents upon the same species, target as well as non-target, are a sort of tri-trophic interaction worth contemplating. An example is insect-vectored plant pathogens, which could magnify both the damage and the number of species attacked beyond that of the herbivore or the pathogen alone. This scenario is approached in the biological control of thistles in North America. Both $R$. conicus and Trichosirocalus horridus, which attack non-target native thistles, can vector Puccinia carduorum, an introduced rust disease of weedy thistles. Fortunately, the rust did not infect the non-target, native thistles tested in laboratory and field studies (Bruckart et al., 1996). This situation bears watching because the insects may vector the rust to other, possibly susceptible, native thistles. The levels of innoculum reaching non-target thistles could be greater than what would arrive through aerial transmission alone. If combined, herbivore-pathogen effects can enhance the damage to target weeds; they could also increase non-target effects. 


\section{Differences between natural and cultivated systems}

Ecologists have a fair knowledge of indirect interactions in a few systems. Some of the best known are among algae and invertebrates in the rocky intertidal (Menge, 1995), among plankton and fish in some lakes (Carpenter and Kitchell, 1993), and among lizards, spiders and prey insects on small Caribbean islands (Schoener and Spiller, 1999). Most analyses of indirect interactions are based upon a subset of species that are obvious or otherwise accessible to researchers while the remainder of the food web is less well known. Analyses of these subsets have been termed 'interaction webs' (Menge and Southerland, 1976), and more recently 'community modules' (see Holt and Hochberg, Chapter 2, this volume). The ecological dynamics of modules can be understood as a mathematical network of interactions, and the analyses of modules have yielded ecological insights about the potential for indirect interactions to affect communities. In nature, community modules are connected to yet other species by interactions that are only poorly known, and knowledge fades at the edges of modules into a form that is reminiscent of a vignette. These lesser-known influences can affect the dynamics of the module. Understanding how modules fade into vignettes is a way of taking account of our ignorance (Strong, 1999).

\section{Risks of biological control}

A discussion of the risks of biological control to native species, both direct and indirect, is meant to foster sensible means for dealing with these risks. The enthusiasm of advocates can exceed the need for biological control, and without sufficient care it can misfire. The use and harm to native species by some introduced biological control agents has led to questions about the safety, rationale and even the need for some projects (Miller and Aplet, 1993; Civeyrel and Simberloff, 1996; Simberloff and Stiling, 1996; Hager and McCoy 1998; Lockwood, 1999). In this section we will assess some of the most prominent risks of biological control, acknowledging that some risks may yet be undiscovered or at least under-appreciated. At the same time, we have emphasized in the introduction that biological control is a valuable tool for conservation as well as for agriculture. Balancing the benefits against the risks is the task at hand. In the final section we will suggest steps toward reform that will reduce the risk to native species and environments. Reform is necessary for sustaining the public trust in this powerful technique.

While classical biological control has been practised for more than 100 years, focused scholarship on non-target effects is only about 20 years old (Andres, 1980; Howarth, 1983). From the inception of this sobering literature, vertebrates have been flagrant, bad actors. The polyphagous 
nature of vertebrates almost always makes them unsuitable for biological control. One poignant example is the cane toad, Bufo marinus, introduced to Australia in 1935 in an abortive attempt to biologically control introduced insect pests of sugar cane (Burnett, 1997). It has spread to occupy over 0.5 million $\mathrm{km}^{2}$. It continues to spread linearly at about $40 \mathrm{~km} \mathrm{year}^{-1}$ and by leap-frogging, as in the recent arrival of cane toad in Western Australia (Callaghan, 2000). Unlike Australian amphibians, this tropical American toad is exceedingly toxic and can kill Australian predators that attempt to eat it. Snakes, goannas (Varanus monitor lizards), birds and carnivorous marsupials such as the small quoll possum, Dasyurus hallucatus, are especially at risk. The high populations and indiscriminate, large appetites of cane toads lead to wholesale consumption of small, native ground-dwelling vertebrates and invertebrates (Niven, 1988). Other vertebrates causing distinct non-target effects include the Indian mongoose, Herpestes javanicus, which is inferred to have caused the extinction of several native reptiles on Caribbean and Pacific islands (Honegger, 1981). In a manifestation of the indirect interaction termed 'apparent competition', feral house cats and red fox feed primarily upon introduced rabbits and house mice, and with this dietary subsidy maintain populations that threaten native marsupials and birds in Australia (Groves and Burdon, 1986; Risbey et al., 1999).

In a criticism of mentioning the past errors of vertebrate use, some biological control researchers have asserted that the cases discussed above are just 'stories from the past'. However, consider the polyphagous, alien grass carp introduced into the USA in 1963 for the biological control of aquatic weeds and still used widely (Julien, 1992; Bain, 1993). In response to a similar accusation that raising the issue of the cane toad is 'hysterical' and 'alarmist', consider the current legislative climate in the state of Mississippi, USA, which is encouraging biological control of snails in commercial catfish ponds with the alien black carp, Mylopharyngodon piceus. This fish is a generalist consumer of molluscs, and poses a substantial risk to native clams and snails in the Mississippi drainage and beyond (Nico and Williams, 1996; Nico, 1999). This area is a centre of biodiversity for freshwater molluscs, especially unionid clams (McMahon, 1991; Stein et al., 2000).

Emphasis upon the ecological safety of biological control has increased in the last 15 years (Pemberton, 1985a,b; Turner, 1985). Many of our presently serious non-target problems of biological control are being caused by agents introduced when attitudes were tilted in favour of agriculture and when dangers to native species were discounted or even ignored. (However, note that the case of the black carp indicates that risks from attitudes that discount the environmental harm of biological control are very much with us in the new millennium.) Thus, in 1957, the voracious Argentine caterpillar Cactoblastis cactorum was introduced to the Caribbean, without regard to the rich native Opuntia flora in perilously close continental North America. Appearing in Florida in 1989, either as an introduction 
of the nursery trade or as a natural migrant (Pemberton, 1995), C. cactorum now attacks five native Florida opuntias, including the rare semaphore cactus (Johnson and Stiling, 1996). Likewise, in 1968, the weevil $R$. conicus was introduced from Europe for control of weedy thistles, even with evidence in hand that it might feed upon native North American thistles. Now widely distributed, it feeds upon the seeds of at least 22 native thistles, including several that are rare (Louda et al., 1997; Pemberton, 2000; see also Gassmann and Louda, Chapter 8, this volume). Perhaps the most egregious harm from biological control followed the 1977 introduction to the Pacific Island of Moorea of the predatory land snail E. rosea, from Florida and Central America. This failed attempt to control the giant African snail instead caused the extinction of seven species and perhaps the entire endemic genus of Partula snails (Murray, 1993). This generalist predator has also harmed native snail fauna of other Pacific islands (Cowie, 1998).

What of the risks of indirect effects of non-target attacks in biological control? We argue that, although not much is known on this topic, the potential risk of indirect harm to native species is great. The classical theory of a nature comprised of short unbranched food chains in which indirect interactions were limited to trophic cascades (Hairston et al., 1960) has been replaced by theories of reticulate food chains rich in possibilities for indirect effects. In modern theories, the results of food web interactions depend upon the details of linkages between species (Polis and Strong, 1996). Newer ideas of multiple predators, herbivores and plant species, variously cross-linked, complement the simpler, original idea of the generality of the trophic cascade. Insect predators are often attacked by yet other predators. The implication is that the actions of biological control agents are contingent upon the other species in the food web (Rosenheim, 1998). Biological control agents commonly have interactions with entomopathogenic viruses, bacteria, fungi and nematodes, as well as with a range of insect predators and parasitoids. These intra-guild predators, resource competitors and community mutualists can have a great influence on the effects of consumers. Food webs are a frontier of ecology, and the science of non-target effects of biological control agents in food webs is in its youth.

\section{Weed biological control}

The science of predicting risks is much more advanced for the biological control of weeds than for insects. This statement is based upon a general assessment of the risk to non-target, native plants posed by insects introduced for biological control with data on field host use of 112 insects, three fungi, one mite and one nematode established for biological control of weeds in Hawaii, the continental USA and the Caribbean against 55 weed species since 1902 (Pemberton, 2000). Of the 112 species of insects introduced for biological control, 15 use 41 native plant species, 36 of 
which are congeneric with target weeds, while four others belong to two closely allied genera. Only one of 117 established biological control organisms uses a native plant unrelated to the target weed. This demonstrates that virtually all non-target risk is borne by native plant species that are closely related to target weeds. Thus the elements of protection for the native flora are the selection of weed targets that have few or no native congeners and the introduction of biological control organisms with suitably narrow diets.

\section{Insect biological control}

The risks to native insects and other invertebrates caused by biological control are poorly known compared with those for weed biological control (Ehler, 1998; Jewel et al., 1999). The potential expense to agriculture and other industries of non-target uses of plants by agents introduced for weed biological control has always been great, and attention to avoiding nontarget economic damage has a long history (even if this attention has only recently been applied seriously to protecting wild native plants). While attention to ecological safety is increasing in some quarters of insect biological control (Ehler, 1998), it is far from universal and often ecologically unsophisticated (Lockwood, 1999). Another important consideration is that insects are inconspicuous, and lists of potential native, non-target species are difficult to establish and woefully incomplete. Most native insect faunas are poorly known and there has been insufficient interest in non-target insect species. A big element in the poor development of safety for entomophages is that insects and other invertebrates have far fewer advocates than do plants. With the exception of pollinators, they have little immediate commercial value, and society has an extremely poor appreciation of the ecological value of insects.

\section{Parasitoids and general predators}

Most of the known non-target attacks upon native insects are attributable to introduced parasitoids, which leave more distinctive evidence than do predators (Funasaki et al., 1988; Barratt et al., 1997). While a lack of taxonomic knowledge of most parasitoid groups hinders the resolution of the data (Memmott, 1999), we do know that scores of introduced parasitoid species attack native insects (Hawkins and Marino, 1997). Although non-target effects are poorly known, parasitoids introduced long ago can harm native herbivore populations today (Boettner et al., 2000). While some parasitoid species are extremely narrow in their host range, some generalist predators occupy the opposite end of the spectrum and have the ability to attack many native species where they are introduced. The most 
general of predators have a number of prey species, which can vary with life history stage, with the seasons, and with the place of foraging as these vary with life history and season.

Trophic relationships between entomophages and hosts or prey are more diverse than those between herbivores and plants. In an inclusive statistical analysis of 68 life tables of introduced and native insects, Hawkins et al. (1999) showed that biological control of insects results in less reticulate trophic relationships than those in natural food webs of native insects. For native generalist predators, food web reticulation and complex interconnections are the mode for suites of multiple interactions between native insects, herbivores and plants. Suites of generalist predators utilize each prey species, making suppression of a herbivore a joint effort. The analysis, based upon literature records, found that the reticulations of native food webs contrast with the mode in biological control in cultivated habitats in which single introduced parasitoid species control single exotic insect herbivores on exotic plants. The cases included in the analysis concerned species of insect herbivores for which at least five generations or a combination of five generations and sites of life table data were measured. Although measured key factors are not necessarily the only influences upon temporal variation in population, they are the best available means for synoptic, general assessment of direct influences of a consumer upon a resource population. The key factors were classified as either parasitism, predation, disease or 'other' causes. The category of other causes included items such as decrease from maximum fecundity, migration and competition with other herbivore species. Some studies revealed more than one key factor, and the assessment included a total of $80 \mathrm{key}$ factors for the 68 life tables.

An implication from Hawkins et al. (1999) was that the sort of biological control of insect herbivores that most frequently succeeds in agriculture is not a 'strictly natural phenomenon'. The short linear food chains of biological control differ from native entomophagous food webs, in which the modal pattern is reticulation of trophic relationships. This is not to say that strong, single-species links with one enemy species controlling one resource species do not exist, because good examples are known (Schmitz et al., 1997; Moran and Hurd, 1998). However, this statistical evidence of complex links in natural food webs complements a literature that proposes that more diverse communities are tied together by multiple trophic influences among species (Strong, 1992; Polis and Strong, 1996).

In native systems, generalist predators and polyphagous parasitoid species contribute a substantial amount to control. The dynamics of natural systems are a result of multiple links in food webs, many of which are overlapping and individually much less forceful than the links in cultivated systems. This is consistent with the idea that populations of native predators rely upon a series of prey species, perhaps in a series of habitats, rather than upon a single prey species in a single habitat. It is also consistent with the 
notion that in persisting and being available at the right time and place to prey upon a herbivore, the generalist predator is 'subsidized' by a range of other prey species. One can term this kind of polyphagous, subsidized existence for general predators a kind of omnivory. It can operate within life history stages or between them, with larvae relying upon different prey species from adults of a generalist predator (Polis and Strong, 1996; Rosenheim, 1998).

The elements and facets of native arthropod communities that we have discussed above indicate substantial complexity of food webs and trophic linkages. It is this complexity into which biological control agents are introduced. Unanticipated consequences follow from unanticipated complexity, and a prime example is given by the now-discontinued programme of biological control of native rangeland grasshoppers in North America (Goodwin, 1993). Among the non-target species likely to be affected by the proposed programme was the native grasshopper Hesperotettix viridis, which feeds primarily upon snakeweed species, Gutierrezia spp. Snakeweeds are among a group of poisonous native plants that cause great losses to cattle that ingest them (Lockwood, 1999).

\section{Ladybird beetles}

Ladybird beetles are particularly germane to issues of indirect interactions and non-target effects in biological control (Obrycki et al., 1999). As of 1985, 179 coccinellid species had been intentionally imported to the United States, 16 of which appear to have become established (Gordon, 1985). Additional ladybird beetles have been imported since then. Five alien ladybird beetles are generalist feeders that have dispersed through substantial portions of North America. Their spread has been hastened by efforts to propagate and introduce them to new areas for the purposes of biological control of pest aphids. The diets of alien ladybird beetles in North America are diverse: some are restricted to mites and others to scales, while still others specialize upon mealybugs, and many are generalist predators. They range among different habitats and feed upon a range of prey species. They can consume prey species that are in the diets of native entomophagous species, such as diets of native ladybird beetles that can be involved in natural biological control of native herbivore species. Consistent with their designation as generalists, the prey of generalist coccinellid beetles is defined less by taxonomic relatedness than by size, location on the plant and habitat.

The introduced ladybird beetles raise red flags of particular risks to the multiple relatively weak links in natural communities. Obrycki et al. (1999) observe that although the data are not particularly good, the current diversity of coccinellid species in parts of the Midwestern USA appears to be lower than that shown in studies before 1950 . While the declines certainly 
could be the product of the multiple habitat changes and even changed climate, one focused study suggests otherwise. Patterns in what was judged to be a pertinent habitat variable - reduction in the lucerne crop over a 18 year period - were uncorrelated to the change in the structure of the coccinellid communities (Elliott et al., 1996). Competition and intra-guild predation with introduced coccinellid species are more likely causes of the decrease in diversity of the native coccinellids. It has been noted by other authors that competition with native generalist predators from introduced general predators can be a greater risk to biological diversity than to the prey of the introduced species (Simberloff and Stiling, 1996; Samways, 1997). Propagation and spread of previously introduced ladybird beetles could contribute to attacks upon native insects. Examples include the seven spot and Harmonia axyridis ladybirds which are general predators that consume a wide variety of prey as well as the pest aphids that are their targets (Obrycki et al., 1999).

\section{The campaign against Russian wheat aphid}

New entomophagous species with broad diets continue to be introduced into North America. A case in point is the campaign against the Russian wheat aphid, which introduced 29 new species of general predators, and parasitoids, and two new forms of two fungi species to 16 states between 1986 and 1993 (Anonymous, 1993; Quisenberry and Peairs, 1998). The programme bred and released over 8.5 million individuals, including more than 1 million individuals of 12 species of ladybird beetles new to North America. Although some research on the biology of these species was carried out during the programme, a philosophy of first studying candidate enemy species was rejected in favour of collecting and releasing as many species of potential enemies as quickly and in as many sites as possible (Prokrym et al., 1998). At the same time '. . . few sound criteria and techniques were available for making such choices' (Hopper et al., 1998). The rationale was urgency felt for the need to control this pest (Prokrym et al., 1998). One evaluation of the campaign was that the limited evidence available indicated that the introduced natural enemies have had little influence upon densities of Russian wheat aphid in the USA (Hopper et al., 1998). Another evaluation (Prokrym et al., 1998) was that any assessment of efficacy was hampered by the limited information gathered. It was difficult to distinguish taxa believed to have been released from native North American species and species released previously, and the scientists worked without adequate biological or ecological information. Prokrym et al. (1998) ventured the opinion that biological control of a pest aphid on an annual crop in vast acreages of monoculture was not bound to succeed. The literature on control of Russian wheat aphid is large and diverse, and of the 200 publications we have reviewed, some 60 indicated an interest in 
biological control. The number making reference to non-target effects of introduced enemies of the Russian wheat aphid is quite small, however. In addition to those cited above, one can add Elliott et al. (1994) and Hammon and Peairs (1998). With the caution that we probably have missed some literature, it is fair to say that not much is known about non-target effects of these alien predators and parasitoids, because little was invested in understanding the potential to harm the native North American biota in the campaign against the Russian wheat aphid.

\section{Reform of biological control}

Restraint is the key to safe biological control. Judicious winnowing of potential targets comes first. Not every invasive species is a threat, and not every pest is appropriate for biological control. Native organisms are the riskiest of targets. Even pestiferous natives can have substantial and complex ecological roles. Natives are linked by trophic interactions to other natives. The discontinued biological control programmes against mesquite, Prosopus glandulosa, and against rangeland grasshoppers (Lockwood, 1999) illustrate the issues. First, for society as a whole, the pest status of these is equivocal. Though both are a problem for some ranchers, both are also substantial components of native communities, with trophic links to many other species. This means that biological control could cause unexpected indirect effects. In contrast, the balance of benefit to risk of biological control against native insects that attack row crops, including corn rootworm, cotton bollworm and Colorado potato beetle, is much greater because of the very great economic value of these crops and the large amount of insecticide that biological control replaces in these cases. However, we hasten to caution that introduced enemies of native pests of row crops can harm other native species that are not pests. Our society has invested very little in the science of understanding collateral damages to native insects caused by biological control agents, and this is an important area for future research attention by both general ecologists and the biological control community. For these reasons, we suggest that native organisms should be targets for biological control under only extreme circumstances. When they are, special study of collateral effects is needed.

Not every available natural enemy promises relief. The continuing tendency to import multiple agents in a sort of post hoc lottery search for some or even one that will do the job increases the probability of non-target attacks upon the native biota (McEvoy and Coombs, 1999). It also justifies the judgement that some biological control is ill advised or misdirected. What is the scientific basis for the choice of the particular enemies and for the large number of enemies in the campaign against Russian wheat aphid? Were all 29 newly introduced foreign species needed? What was the expected benefit of each species relative to its risk to the native 
biota? We suggest that weighing evidence of efficacy should be part of all biological control projects, in an effort to import the fewest foreign enemy species possible.

The basis of ecological safety in biological control is suitably narrow diets of agents. For weeds, the statistics show that native plants most closely related to the target weed have the highest risk (Pemberton, 2000). Thus, the safest targets are weeds without close native relatives in the region (Pemberton, 1996). A good example is tamarisk, a species complex of trees from Eurasia that invade natural wetlands and watercourses throughout the south-western USA. Tamarisk plants deplete surface water and displace natural vegetation such as cottonwood, willow and mesquite. Notwithstanding the possibility that some macroevolutionary insect herbivore shifts can be mediated by plant chemistry not revealed by plant taxonomy (Becerra and Venable, 1999), it is proposed that an ecologically safe insect herbivore for control of tamarisk plants in America need only be restricted in diet to the family Tamaricaceae. This is based upon the fact that the western hemisphere lacks natives in this plant family (Deloach et al., 1996).

Many pests, however, do have native relatives in areas where they have been introduced, meaning that the diet of an agent must be suitably narrow, so as not to threaten natives. For example, even the relatively stenophagous herbivores of European thistles are not sufficiently specific to prevent their adoption of a number of the 90 native North American Cirsium thistle species. Five biological control agents have been introduced against Carduus thistles and two are known to use native thistles. Current knowledge is that $R$. conicus now uses 22 of the 90 native Cirsium in the USA (Pemberton, 2000). What is to prevent $R$. conicus from using additional native North America Cirsium spp.? For example, the Sacramento thistle, Cirsium vinaceum, Woot. and Standl., in New Mexico is a good host in the laboratory, but the weevil has not yet spread into its range ( $R$. Lee, personal communication). The weevil $T$. horridus feeds upon the native Cirsium discolor (Muhl. ex Willd.) Spreng. in Virginia (McAvoy et al., 1987) and could probably use other Cirsium spp. because it attacks rosettes, which are available over all or most of the season. By contrast, $R$. conicus is restricted in host use to the flower buds of Cirsium spp. that are available during its oviposition period (see Gassmann and Louda, Chapter 8, this volume).

The greatest attention to safety has been with the biological control of weeds because collateral damage to agricultural plants is expensive. The United States, like all but a few countries, has no laws created specifically for biological control. Old statutes barring alien species harmful to agriculture have been applied to regulate importation of agents against weeds. Regulation is in the hands of the Animal and Plant Protection Service of the Department of Agriculture, guided by the Federal Plant Pest Act of 1957, the Plant Quarantine Act of 1912 and the Noxious Weed Act of 1974. In recent years, protections have been extended to native plants, consistent with The National Environmental Policy Act of 1970, which 
requires Federal activities to consider possible environmental effects. The Animal and Plant Health Inspection Service review begins with a evaluation petition submitted by a scientist. Petitions are then reviewed by a Technical Advisory Group ('TAG'), with members representing different resource interests within the Federal government. If the Technical Advisory Group recommends approval, the petitioning scientist submits an application for a release permit through his or her state department of agriculture. The Animal and Plant Health Inspection Service then prepares an Environmental Assessment. If there results a 'Finding of No Significant Impact' ('FONSI') and the US Fish and Wildlife Service which consults on the Environmental Assessment concurs, a release permit is issued. We suggest that a review process like this, with important changes, is a good template for improved practice. The changes should include external expert review of petitions and a more transparent process such as posting of the petitions, the external reviews and Technical Advisory Group recommendations on the Internet. The appropriate government agency for the regulation of biological control should be chosen after national discussion of these issues (Anonymous, 1995).

Most native insects, mites and other invertebrates lack the key combination of legal regulatory protections afforded to plants from harm caused by biological control introductions. Although the ecological and economic value of invertebrates is not widely appreciated, these species are crucial to the ecological integrity of our wild, urban and agricultural landscapes. Their lack of protection is alarming because of their substantial role in nature (Strong et al., 1984). Native herbivorous insects and mites control plants that could become pests in the absence of this natural control. Invertebrate predators, parasites and parasitoids control herbivores, both native and alien, that could severely harm vegetation. Indirect interactions among native invertebrates, which can be threatened by alien species, contribute additional glue to our natural communities. Neither evidence of efficacy nor that of safety is required for introduction of organisms that have insects and mites as targets. The US Animal and Plant Health Inspection Service has no clear authority to exclude species other than those that threaten plants, pollinators and established biological control organisms, except by invoking the National Environmental Policy Act. However, neither state nor other non-Federal activities are regulated by this Act.

The sensible course is to extend protection to all native organisms, with carefully chosen exceptions made for the small number of unequivocally serious native pests. The current US Animal and Plant Health Inspection Service review for weed biological control is a good model: we recommend that a process of petition and expert review is the legal avenue required for all biological control introductions, herbivorous and carnivorous alike. All proposed introductions should meet stringent criteria of need, appropriateness, efficacy and ecological safety. Is the proposed target a serious pest 
or does it threaten to become one? Is biological control the appropriate approach to control? Is the proposed agent sufficiently harmful to suppress the pest? Is the proposed agent safe? The evidence on safety should define the probable risks to native and other valuable species by means of data on hosts or prey in the native, origin area of the candidate as well as results of rigorous host-prey specificity and range testing. The ad hoc Technical Advisory Group review should be open and include experts from the spectrum of appropriate government, university and private organizations. Finally, there is need to more carefully regulate propagation, re-release and movement of biological control organisms after their introduction. The issuance of an Animal and Plant Health Inspection Service permit for release is usually the end of effective Federal oversight. While states can regulate movement of an agent, usually they do not. With few exceptions, state regulators defer to judgement of USDA-APHIS about the safety of agents for their state. 'Safety' usually concerns agriculture and not native organisms. This means that, once in the USA, the knowledge that native species are threatened by a biological control organism serves for little in preventing its propagation and spread. For example, in the case that no native molluscs were threatened or endangered, the Endangered Species Act could not be invoked, and little if any effective Federal regulatory impediment could be brought against the dissemination of the black carp among catfish farms. How likely is escape of this voracious mollusc-feeder into the Mississippi drainage? Likewise for movement of alien ladybird beetles which threaten native predacious insects; for $R$. conicus which threatens native thistles; and for $C$. cactorum which threatens native and commercial Opuntia in Mexico and the USA.

Introduced natural enemies do not respect political boundaries. Increasing the general ecological safety of biological control in the USA could provide guidance for the more challenging international implications of this technology. Important examples include agents released in Canada that migrate to the USA, and C. cactorum which, now in Florida, could move into Mexico to threaten the large industries based on Opuntia there. The spectre of $C$. cactorum moving west from Florida to attack 60-odd species of native Opuntia in the USA and south to attack the native and commercial Opuntia in Mexico illustrates how biological control is both a national and an international issue. Some of the most threatening invasive species are marine, and biological control is being contemplated as one technique for dealing with these aliens. Most oceans span boundaries and nations will soon need to address the transborder issues of marine biological control (Bax et al., 2000). Countries are responsible for their own regulation of biological control introductions into their territory. The ecologically motivated reforms discussed here (the appropriate use of biological control, for a carefully selected subset of pests, and the utilization only of natural enemies with suitably narrow diets) will, however, reduce the risk of biological control to non-target native organisms everywhere. 
We suggest the following additional guidelines to assist the management of biological control:

1. The practice of biological control should be separated from its regulation.

2. The participation of different resource-based government agencies (i.e. environmental protection, agriculture, forestry, fisheries, etc.) should be encouraged in decisions on biological control.

3. External review and comment should be part of the process.

4. The process should be transparent to the public. Information relating to proposed introductions, safety testing and decision-making can be posted on the Internet and in other appropriate media.

We also suggest that guidelines for reducing the risk of biological control to non-target native organisms, perhaps incorporating the ideas discussed in this chapter, be considered to strengthen the United Nations FAO 'Code of Conduct for the Import and Release of Exotic Biological Control Agents' (FAO, 1996; Greathead, 1997). With invasive species just as with many environmental issues, doing nothing is not neutral. Imported natural enemies are the last best hope to parry some of the most damaging exotic pests in natural areas as well as in agriculture. However, in the absence of reform, opposition to biological control - rational as well as irrational - will grow. A few sensible steps such as those that we suggest herein will maintain public confidence and support for this powerful tool for use against invaders of natural areas as well as in agriculture.

\section{References}

Andres, L.A. (1980) Conflicting interests and the biological control of weeds. In: Delfosse, E.S. (ed.) Fifth International Symposium on the Biological Control of Weeds. CSIRO, Brisbane, Australia, pp. 11-20.

Anonymous (1993) Unpublished report. USDA-APHIS, Niles Michigan Laboratory. Anonymous (1995) Biologically Based Technologies for Pest Control, September 1995. US Office of Technology Assessment, Washington, DC.

Baggen, L.R., Gurr, G.M. and Meats, A. (1999) Flowers in tri-trophic systems: mechanisms allowing selective exploitation by insect natural enemies for conservation biological control. Entomologia Experimentalis et Applicata 91, 155-161.

Bain, M.B. (1993) Assessing impacts of introduced aquatic species: grass carp in large systems. Environmental Management 17, 211-224.

Barratt, B.I.P., Evans, A.A., Ferguson, C.M., Barker, G.M., McNeill, M.R. and Phillips, C.B. (1997) Laboratory nontarget host range of the introduced parasitoids Microctonus aethiopoides and $M$. hyperodae (Hymenoptera: Braconidae) compared with field parasitism in New Zealand. Environmental Entomology 26, 694-702.

Bax, N., Carlton, J.T., Mathews-Amos, A., Haedrich, R.L., Howarth, F.G., Purcell, J.E., Reiser, A. and Gray, A. (2000) Conserving marine biodiversity: the control of biological invasions in the world's oceans. Conservation Biology' (in press). 
Becerra, J.X. and Venable, D.L. (1999) Macroevolution of insect-plant associations: the relevance of host biogeography to host affiliation. Proceedings of the National. Academy of Sciences USA 96, 12626-12631.

Boettner, G.H. (2000) Impacts of an introduced generalist fly parasitoid on three nontarget native species of saturniid moths. Conservation Biology (in press).

Bruckart, W.L., Politis, D.J., Defago, G., Rosenthal, S.S. and Supkoff, D.M. (1996) Susceptibility of Carduus, Cirsium, and Cynara species artificially inoculated with Puccinia carduorum from musk thistle. Biological Control 6, 215-221.

Burnett, S. (1997) Colonizing cane toads cause population declines in native predators: reliable anecdotal information and management implications. Pacific Conservation Biology 1, 65-72.

Callaghan, R. (2000) Queensland cane toad takes a long leap west. The West Australian (newspaper), 20 March, 2000. Web edition <http://www.thewest. com.au/20000320/News/new-per-sto6-bod.html>.

Carpenter, S.R. and Kitchell, J.F. (1993) The Trophic Cascade in Lakes. Cambridge University Press, New York.

Center, T.D., Frank, J.H. and Dray, F.A. (1997) Biological control. In: Simberloff, D.S., Schmitz, D.C. and Brown, T.C. (eds) Strangers in Paradise: Impact and Management of Non-indigenous Species in Florida. Island Press, Washington, DC, pp. 245-263.

Chesson, P. (2000) Mechanisms of maintenance of species diversity. Annual Review of Ecology and Systematics (in press).

Cisneros, J.J. and Rosenheim, J.A. (1997) Ontogenetic change of prey preference in the generalist predator Zelus renardii and its influence on predator-predator interactions. Ecological Entomology 22, 399-407.

Civeyrel, L. and Simberloff, D. (1996) A tale of two snails: is the cure worse than the disease? Biodiversity and Conservation 5, 1231-1252.

Clark, K.B., Jensen, K.R., Meinesz, J., Norris, J.N. and Pemberton, R. (2000) Considerations for biological control of the exotic marine alga Caulerpa taxifolia (Vahl) C. Agardh by Sacoglossan (=Ascoglossan) molluscs. Marine Ecology Progress Series (in press).

Colton, T.F. and Alpert, P. (1998) Lack of public awareness of biological invasions by plants. Natural Areas Journal 18, 262-266.

Cowie, R.H. (1998) Patterns of introduction of non-indigenous non-marine snails and slugs in the Hawaiian Islands. Biodiversity and Conservation 7, 349-368.

Deloach, C.J., Gerling, D., Fornasari, L., Sobhian, R., Myartseva, S., Mityaev, I.D., Lu, Q.C., Tracy, J.L., Wang, R., Wang, J.F., Kirk, A., Pemberton, R.W., Chikatunov, V., Jashenko, R.V., Johnson, J.E., Zheng, H., Jiang, S.L., Liu, M.T., Liu, A.P. and Cisneroz, J. (1996) Biological control programme against saltcedar (Tamarix spp.) in the United States of America: progress and problems. In: Moran, V.C. and Hoffmann, J.H. (eds) IX International Symposium on Biological Control of Weeds. University of Cape Town, Stellenbosch, South Africa, pp. 253-260.

Ehler, L.E. (1998) Invasion biology and biological control. Biological Control 13, $127-133$.

Elliott, N., Kieckhefer, R. and Kauffman, W. (1996) Effects of an invading coccinellid on native coccinellids in an agricultural landscape. Oecologia 105, 537-544.

Elliott, N.C., French, B.W., Burd, J.D., Kindler, S.D. and Reed, D.K. (1994) Parasitism, adult emergence, sex ratio, and size of Aphidius colemani 
(Hymenoptera: Aphidiidae) on several aphid species. Great Lakes Entomologist $27,137-142$.

Fagan, W.F. (1997) Omnivory as a stabilizing feature of natural communities. American Naturalist 150, 554-567.

FAO (Food and Agricultural Organization) (1996) Code of conduct for the import and release of exotic biological control agents. International Standards for Phytosanitary Measures (ISPM), publication no. 3. FAO, Rome.

Ferguson, K.I. and Stiling, P. (1996) Non-additive effects of multiple natural enemies on aphid populations. Oecologia 108, 375-379.

Frank, J.H. (1999) Bromeliad-feeding weevils. Selbyana 20, 40-48.

Funasaki, G.Y., Lai, P.Y., Nakahara, L.M., Beardsley, J.W. and Ota, A.K. (1988) A review of biological control introductions in Hawaii, USA, 1890 to 1985. Proceedings of the Hawaiian Entomological Society 28, 105-160.

Goodwin, B. (1993) Research community swats grasshopper trial. Science 260, 887.

Gordon, R.D. (1985) The Coccinellidae (Coleoptera) of America north of Mexico. Journal of the New York Entomology Society 93, 1-912.

Greathead, D.J. (1997) An introduction to the FAO code of conduct for the import and release of exotic biological control agents. Biocontrol News and Information $18,119-124$.

Grewal, S.K. Grewal, P.S. and Gaugler, R. (1995) Endophytes of fescue grasses enhance susceptibility of Popillia japonica larvae to an entomopathogenic nematode. Entomologia Experimentalis et Applicata 74, 219-224.

Groves, R.H. and Burdon, J.J. (1986) Ecology of Biological Invasions: an Australian Perspective. Australian Academy of Science, Canberra, Australia.

Hager, H.A. and McCoy, K.D. (1998) The implications of accepting untested hypotheses: a review of the effects of purple loosestrife (Lythrum salicaria) in North America. Biodiversity and Conservation 7, 1069-1079.

Hairston, N.G., Smith, F.E. and Slobodkin, L.B. (1960) Community structure, population control, and competition. American Naturalist 94, 421-425.

Hammon, R.W. and Peairs, F.B. (1998) Exploration for natural enemies to control Diuraphis noxia (Homoptera: Aphididae) in the United States. In: Quisenberry, S.S. and Peairs, F.B. (eds) Response Model for an Introduced Pest: the Russian Wheat Aphid. Entomological Society of America, Thomas Say Publications in Entomology, Lanham, Maryland, pp. 280-287.

Hawkins, B.A. and Marino, P.C. (1997) The colonization of native phytophagous insects in North America by exotic parasitoids. Oecologia 112, 566-571.

Hawkins, B.A., Mills, N.J., Jervis, M.A. and Price, P.W. (1999) Is the biological control of insects a natural phenomenon? Oikos 86, 493-506.

Holt, R.D. and Lawton, J.H. (1993) Apparent competition and enemy-free space in insect host-parasitoid communities. American Naturalist 142, 623-645.

Holt, R.D. and Polis, G.A. (1997) A theoretical framework for intraguild predation. American Naturalist 149, 745-764.

Honegger, R.E. (1981) List of amphibians and reptiles either known or thought to have become extinct since 1600. Biological Conservation 19, 141-158.

Hopper, K.R., Coutinot, D., Chen, K., Kazmer, D.J., Mercadier, G., Halbert, S.E., Miller, R.H., Pike, K.S. and Tanigoshi, L.K. (1998) Exploration for natural enemies to control Diuraphis noxia (Homoptera: Aphididae) in the United States. In: Quisenberry, S.S. and Peairs, F.B. (eds) Response Model for an Introduced Pest: 
the Russian Wheat Aphid. Entomological Society of America, Thomas Say Publications in Entomology, Lanham, Maryland, pp. 166-182.

Howarth, F.G. (1983) Classical biocontrol: panacea or Pandora's box. Proceedings of the Hawaiian Entomological Society 24, 234-244.

Janssen, A., Pallini, A., Venzon, M. and Sabelisi, M.W. (1998) Behaviour and indirect interactions in food webs of plant-inhabiting arthropods. Experimental and Applied Acarology 22, 497-521.

Jewel, J.J., O'Dowd, D.J., Bergelson, J., Daehler, C.C., D’Antonio, C.M., Gomez, L.D., Gordon, D.R., Hobbs, R.J., Holt, A., Hopper, K.R., Hughes, C.E., LaHart, M., Leakey, R.R.B., Lee, W.G., Loope, L.L., Lorence, D.H., Louda, S.M., Lugo, A.E., McEvoy, P.B., Richardson, D.M. and Vitousek, P.M. (1999) Deliberate introductions of species: research needs - benefits can be reaped, but risks are high. Bioscience 49, 619-630.

Johnson, D.M. and Stiling, P.D. (1996) Host specificity of Cactoblastis cactorum (Lepidoptera: Pyralidae), an exotic Opuntia-feeding moth, in Florida. Environmental Entomology 25, 743-748.

Julien, M.H. (1992) Biological Control of Weeds. A World Catalogue of Agents and their Target Weeds, 3rd edn. CAB International, Wallingford, UK.

Karban, R. and Baldwin, I.T. (1997) Induced Responses to Herbivory. University of Chicago Press, Chicago.

Levins, R. and Schultz, B.B. (1996) Effects of density dependence, feedback and environmental sensitivity on correlations among predators, prey and plant resources: models and practical implications. Journal of Animal Ecology 65, $802-812$.

Lima, S.L. and Dill, L.M. (1990) Behavioral decisions made under the risk of predation. A review and prospectus. Canadian Journal of Zoology 68, 619-640.

Lockwood, J.A. (1999) Non-target effects of biological control: what are we trying to miss? In: Follett, P.A. and Duan, J.J. (eds) Non-target Effects of Biological Control. Kluwer, Dordrecht, pp. 15-30.

Lonsdale, W.M. and Farrell, G.S. (1998) Testing the effects on Mimosa pigra of a biological control agent Neurostrota gunniella (Lepidoptera: Gracillaridae), plant competition and fungi under field conditions. Biocontrol Science and Technology 8, 485-500.

Louda, S.M., Kendall, D., Connor, J. and Simberloff, D. (1997) Ecological effects of an insect introduced for the biological control of weeds. Science 277, $1088-1090$.

McAvoy, T.J., Kok, L.T. and Mays, W.T. (1987) Dispersal of Trichosirocalus horridus (Panzer) (Coleoptera: Curculionidae) in southwest Virginia. Journal of Entomological Science 22, 324-329.

McEvoy, P.B. and Coombs, E.M. (1999) Why things bite back: unintended consequences of biological control of weeds. In: Follett, P.A. and Duan, J.J. (eds) Non-target Effects of Biological Control. Kluwer, Dordrecht, pp. 167-195.

McFadyen, R.E.C. (1998) Biological control of weeds. Annual Review of Entomology 43, 369-393.

McMahon, R.F. (1991) Mollusca: bivalvia. In: Thorp, J.H. and Covich, A.P. (eds) Ecology and Classification of North American Freshwater Invertebrates. Academic Press, San Diego, California, pp. 315-399. 
Memmott, J. (1999) Food webs as a tool for studying nontarget effects in biological control. In: Follett, P.A. and Duan, J.J. (eds) Non-target Effects of Biological Control. Kluwer, Dordrecht, pp. 147-153.

Menge, B.A. (1995) Indirect effects in marine rocky intertidal interaction webs: patterns and importance. Ecological Monographs 65, 21-74.

Menge, B. and Sutherland, J. (1976) Species diversity gradients: synthesis of the roles of predation, competition and temporal heterogeneity. American Natural ist 110, 351-369.

Messina, F.J., Jones, T.A. and Nielson, D.C. (1997) Host-plant effects on the efficacy of two predators attacking Russian wheat aphids (Homoptera: Aphididae). Environmental Entomology 26, 1398-1404.

Miller, M. and Aplet, G. (1993) Biological control: a little knowledge is a dangerous thing. Rutgers Law Review 45, 285-334.

Mills, N.J. and Gutierrez, A.P. (1996) Prospective modelling in biological control: an analysis of the dynamics of heteronomous hyperparasitism in a cottonwhitefly-parasitoid system. Journal of Applied Ecology 33, 1379-1394.

Moran, M.D. and Hurd, L.E. (1998) A trophic cascade in a diverse arthropod community caused by a generalist arthropod predator. Oecologia 113, 126-132.

Müller, C.B. and Godfray, H.C.J. (1997) Apparent competition between two aphid species. Journal of Animal Ecology 66, $57-64$.

Murray, E. (1993) The sinister snail. Endeavor 17, 78-83.

Nico, L. (1999) Non-indigenous aquatic species, Mylopharyngodon piceus (Richardson 1846). United States Geological Survey web site: <http://nas.er. usgs.gov/fishes/accounts/cyprinid/my_piceu.html>.

Nico, L.G. and Williams, J.D. (1996) Risk assessment on black carp (Pisces: Cyprinidae). Final Report to the Risk Assessment and Management Committee of the Aquatic Nuisance Species Task Force. US Geological Survey, Biological Resources Division.

Niven, B.S. (1988) Logical synthesis of an animal's environment: sponges to non-human primates: V. The cane toad, Bufo marinus. Australian Journal of Zoology 36, 169-194.

Obrycki, J.J., Elliott, N.C. and Giles, K.L. (1999) Coccinellid introductions: potential for and evaluation of nontarget effects. In: Follett, P.A. and Duan, J.J. (eds) Non-target Effects of Biological Control. Kluwer, Dordrecht, pp. 127-146.

Olckers, T. and Hill, M.P. (eds) (1999) Biological Control of Weeds in South Africa (1990-1998), African Entomology Memoir I. Entomological Society of South Africa.

Paine, R.T. (1996) Preface. In: Polis, G.A. and Winemiller, K.O. (eds) Food Webs: Integration of Patterns and Dynamics. Chapman \& Hall, New York, pp. ix-x.

Pearson, D.E., McKelvey, K.S. and Ruggiero, L.F. (2000) Non-target effects of an introduced biological control agent on deer mouse ecology. Oecologia 122, 121-128.

Pels, B. and Sabelis, M.W. (1999) Local dynamics, overexploitation and predator dispersal in an acarine predator-prey system. Oikos 86, 573-583.

Pemberton, R.W. (1985a) Native plant considerations in biological control of leafy spurge. In: Delfosse, E.S. (ed.) Sixth International Symposium for the Biological Control of Weeds. Agriculture Canada, Vancouver, pp. 57-71.

Pemberton, R.W. (1985b) Native weeds as candidates for biological control research. In: Delfosse, E.S. (ed.) Sixth International Symposium for the Biological Control of Weeds. Agriculture Canada, Vancouver, pp. 869-877. 
Pemberton, R.W. (1995) Cactoblastis cactorum (Lep.: Pyralidae) in the United States: an immigrant biological control agent or an introduction of the nursery industry? American Entomologist 41, 230-232.

Pemberton, R.W. (1996) The potential of biological control for suppression of invasive weeds in southern environments. Castanea 61, 313-319.

Pemberton, R.W. (2000) Predictable risk to native plants in weed biological control. Oecologia (in press).

Pemberton, R.W. and Ferriter, A.P. (1998) Old World climbing fern (Lygodium microphyllum), a dangerous invasive weed in Florida. American Fern Journal 88, $165-175$.

Pfennig, D.W. (1997) Kinship and cannibalism. Bioscience 47, 667-675.

Polis, G.A. and Strong, D.R. (1996) Food web complexity and community dynamics. The American Naturalist 147, 813-846.

Prokrym, D.R., Pike, K.S. and Nelson, D.J. (1998) Biological control of Diuraphis noxia (Homoptera: Aphididae): implementation and evaluation of natural enemies. In: Quisenberry, S.S. and Peairs, F.B. (eds) Response Model for an Introduced Pest: the Russian Wheat Aphid. Entomological Society of America, Thomas Say Publications in Entomology, Lanham, Maryland, pp. 183-208.

Quisenberry, S.S. and Peairs, F.B. (1998) Response Model for an Introduced Pest: the Russian Wheat Aphid. Entomological Society of America, Lanham, Maryland.

Risbey, D.A., Calver, M.C. and Short, J. (1999) The impact of cats and foxes on the small vertebrate fauna of Heirisson Prong, Western Australia. I. Exploring potential impact using diet analysis. Wildlife Research 26, 621-630.

Rosenheim, J.A. (1998) Higher-order predators and the regulation of insect herbivore populations. Annual Review of Entomology 43, 421-447.

Samways, M.J. (1997) Classical biological control and biodiversity conservation: what risks are we prepared to accept? Biodiversity and Conservation 6, 1309-1316.

Schmitz, O.J., Beckerman, A.P. and O'Brien, K.M. (1997) Behaviorally mediated trophic cascades: effects of predation risk on food web interactions. Ecology 78, 1388-1399.

Schoener, T.W. and Spiller, D.A. (1999) Indirect effects in an experimentally staged invasion by a major predator. American Naturalist 153, 347-358.

Simberloff, D. and Stiling, P. (1996) How risky is biological control? Ecology 77, $1965-1974$.

Stein, B., Kutner, L.S. and Adams, J.S. (eds) (2000) Precious Heritage: the Status of Biodiversity in the United States. Oxford University Press.

Strong, D.R. (1992) Are trophic cascades all wet? The differentiation and donor-control in speciose ecosystems. Ecology 73, 747-754.

Strong, D.R. (1999) Predator control in terrestrial ecosystems: the underground food chain of bush lupine. In: Olff, H., Brown, V.K. and Drent, R.H. (eds) Herbivores: Between Plants, and Predators. Blackwell Science, Oxford, pp. $577-602$.

Strong, D.R., Lawton, J.A. and Southwood, T.R.E. (1984) Insects on Plants. Harvard University Press, Cambridge, Massachusetts.

Turner, C.E. (1985) Conflicting interests in biological control of weeds. In: Delfosse, E.S. (ed.) Sixth International Symposium for the Biological Control of Weeds. Agriculture Canada, Vancouver, pp. 203-225.

Vinson, S.B. (1999) Parasitoid manipulation as a plant defense strategy. Annals of the Entomological Society of America 92, 812-828. 